\title{
Inflatable Rockbolts at Otter-Juan Mine, Kambalda
}

\author{
M.H. Turner Turner Mining and Geotechnical Pty Ltd, Australia \\ T. Green Goldfields Mine Management Pty Ltd, Australia
}

\begin{abstract}
The Otter-Juan Mine in Kambalda, Western Australia is over $1350 \mathrm{~m}$ deep, with very high stresses and a weak ultramafic hangingwall. Support systems in the ore drives have to cope with severe deformations and seismicity. By mid-2005 the 2-pass support system of split sets and mesh followed by threadbars was becoming difficult to manage due to failure of split sets before the threadbars could be installed. Trials using inflatable rockbolts commenced in August 2005. The trials proved successful and the bolts were introduced as standard ore drive support in June 2006. The trials took far longer than expected due to supply delays and the necessary modifications to equipment required to ensure reliable installation.
\end{abstract}

\section{Introduction}

The Otter-Juan Mine in Kambalda is continuing to stope and develop at ever greater depths and is currently operating at depths exceeding $1350 \mathrm{~m}$ below surface in an extremely aggressive stress environment. Virgin stress levels are over $90 \mathrm{MPa}$ and rock strength around stoping excavations is considerably less than this, leading to significant closure in the ore drives.

Matching the capabilities of the support systems to the rock mass deformations and equipment limitations was becoming increasingly difficult from the middle of 2005.

The support system being used was a two-pass system, with split sets and mesh installed by jumbo in the ore drives as the primary system. Threadbars were then installed by airleg operators between 100 and $50 \mathrm{~m}$ from the face as secondary support. Split sets had already been damaged by rock mass deformation by the time the threadbars were being installed, with ring failures and buckled plates common. As the depth and stress increased the deformation rate also increased, causing split set failures closer to the ore drive faces.

In order to cope with the increased deformation and closure rates the threadbars had to be installed closer to the face but operationally this was proving difficult. The airleg operators and jumbos could not drill close together in the same ore drive at anywhere near the required productivity.

The performance of Swellex quoted in advertising documentation from Atlas Copco indicated that in theory the Mn24 Swellex bolts (manganese steel, 24 t capacity) would be suited to the conditions. Converting to a different type of bolting system in such a harsh environment required trials to ensure the bolts were suitable. The trials were successful and the bolts introduced but only after delays importing bolts for the trial and delays whilst equipment was modified to ensure reliability. Unlike most other bolts, Swellex installations rely on a pump without which the bolts cannot be installed and reliability was a key issue.

\section{History of Otter-Juan}

Otter-Juan is one of the oldest mines in the Kambalda nickel region, having commenced production in 1969. The mine was owned and operated by WMC Resources (WMC) until closure in 1999. The mine was reopened in 2001 by Goldfields Mine Management Pty Ltd (GMM), who sub-leased the mine from WMC. GMM was purchased by Mincor Resources NL (Mincor) in July 2007. To date the mine has produced over 8.3 million tonnes of ore at an average grade of 3.57\% Nickel for a total of 297000 tonnes of Nickel metal worth $\$ 9.3$ billion at the current Nickel price. 


\section{Mining environment}

Current stoping and development operations are deeper than $1350 \mathrm{~m}$. Virgin stresses are very high, with a Major Principal stress of 68.6 MPa measured at a depth of $980 \mathrm{~m}$ using HI cells (AMC, 1998). Extrapolating the rate of increase in stress with depth to the current depth gives $94 \mathrm{MPa}$. The hangingwall ultramafic has an average laboratory uniaxial strength of $76 \mathrm{MPa}$ but contains zones of far weaker material with talc-chlorite veins.

Stresses are very high, rock mass deformation considerable, and the mine has a history of seismic activity. Orebody widths in the current mining area range from 2 to $2.5 \mathrm{~m}$, with dips from $25^{\circ}$ to $40^{\circ}$ and a strike length of 150 to $175 \mathrm{~m}$. The geology of the Kambalda nickel region and of Otter-Juan mine is described by Gresham and Loftus-Hills (1981) and by Banasik (2003).

Ore extraction commences with ore drives developed along the payable strike length by single-boom jumbo. Ore is then mined from slot rises developed off the ore drives at $6 \mathrm{~m}$ centres, with sub-levels developed between the slots to form $5 \times 5 \mathrm{~m}$ pillars. The pillar walls are stripped on retreat achieving an overall extraction of around 70\% (Figure 1). The mining method is explained in detail by Turner et al. (2004).

The support system used in ore drives prior to 2006 was a two-pass system (Turner and Green, 2005). The first pass included split sets and mesh installed to the face by jumbo as part of the development cycle. The second pass support involved resin-anchored threadbars installed by airleg miners between 100 and $50 \mathrm{~m}$ from the face.

The ultramafic forming the backs of the ore drives suffers from time dependent deformation even before slot rising commences. Total ore drive closures of $0.5 \mathrm{~m}$ are typical, with most of this occurring on the hangingwall side of the drives. Extensometers installed after completion of the ore drive development showed deformation of $70 \mathrm{~mm}$ over the first $2 \mathrm{~m}$, but this is in addition to an estimated $150 \mathrm{~mm}$ wall and back deformation the drives have already suffered. Non-linear Map3D modelling indicated an expected wall deformation of $90 \mathrm{~mm}$ per metre at current depths (Turner and Green, 2005).

By mid-2005 split sets were already damaged by rock mass deformation by the time the threadbars were installed, with numerous ring failures and buckled plates. As the depth and stress increased, the deformation rate also increased, causing split set failures closer to the ore drive faces and occasional early rehabilitation. Threadbars were also becoming increasingly difficult to install due to the intensely fractured ground.

In order to cope with the increased deformation and closure rates the threadbars had to be installed closer to the face but operationally this was proving difficult. The airleg operators and jumbos could not drill in the same ore drive closer than $50 \mathrm{~m}$ at anywhere near the required productivity. The limit on productivity was mainly caused by the bogging cycle and the requirement for vehicular access to the jumbo throughout the shift by supervisors, fitters, and nippers etc.

Once installed, threadbars were still performing as required, indicating that their $20 \%$ yield capacity was still sufficient for the rock mass deformations. 


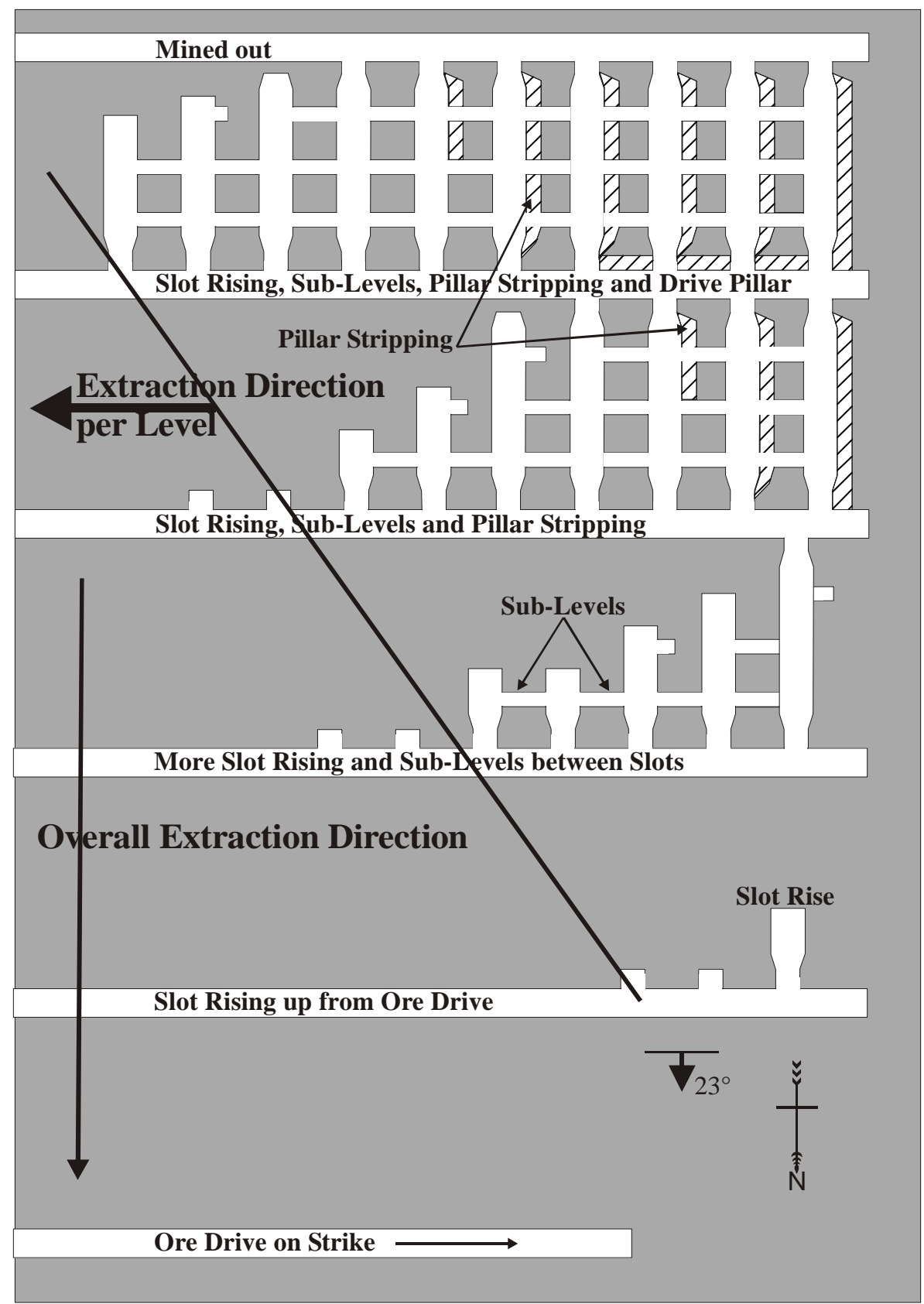

Figure 1 Mining method (Turner and Green, 2004)

\section{Inflatable rockbolt trial}

In August 2005, Swellex trials were started. The objective of the trial was to determine if Swellex bolts could be installed as a single pass bolt to the face, replacing both split sets and threadbars. The initial requirements were that the bolts had to be installable with a jumbo without operational difficulties, be capable of pinning the mesh to the backs and cope with the complete deformation cycle, from development to the end of stoping.

The number of objectives that had to be achieved prior to any changeover increased as the trial progressed and the major objectives are listed below:

- Performance at least as good as threadbars in high deformation ground.

- Withstand seismic deformation and rockbursts.

- Obtain reliable supply source. 
- Ensure consistent quality control.

- Reliable installation equipment.

- Ease of installation.

- Safe installation procedures.

- Blast resistant.

- Resistant to mobile equipment damage.

- Compatible with mesh and mesh overlaps.

Swellex bolts have had a bad reputation in Australia apparently due to a rockfall associated with bolt failure at Mt Isa in the 1980s. Luckily for Otter-Juan, management were still amenable to conducting a trial of the bolts.

In mid-2005 there were only sufficient Swellex bolts in Australia for a small trial. The initial bolts were installed using a hand-held hydraulic pump loaned by Atlas Copco and when these performed successfully the trial was extended. Pull testing of these bolts was undertaken underground. The next stage of the trial, in August 2005 involved importing additional bolts from Sweden, adding another complication to the trial. Critical stages of the trial from June 2005 to August 2007 are listed in Table 1.

The trial was extended in December 2005 to areas requiring rehabilitation, i.e. areas that could be monitored and re-supported if the bolts failed, without a direct impact on production. During this stage of the trial, failures of some bolts were occurring during the inflating stage. Some of these bolts were returned to Atlas Copco and on investigation it appeared the longitudinal welds were sub-standard for some bolts in a particular batch. Replacement bolts did not fail.

The bolts that proved to work best for the conditions were Mn24 bolts, made from Manganese steel, capable of yielding 30\% at $240 \mathrm{kN}$ and installable in standard $45 \mathrm{~mm}$ holes (preferred hole diameter 45 to $51 \mathrm{~mm}$ ).

After a trial period lasting around 12 months the bolts were deemed to have met all the required conditions and in June 2006 an electric pump from Sandvik was installed on a single boom Tamrock Monomatic to facilitate in-cycle Swellex installation in ore drives.

Increasing depths and stresses have also led to strainbursting in the decline and occasional sidewall deformations too severe for split sets. An electric pump was installed on the twin-boom jumbo in May 2007 for installing Swellex to the face in all deep capital development.

The trial also required modifications to installation equipment to improve the quality of installation and to improve the reliability and reduce the cost of the equipment. Locally manufactured pumps and valves were obtained and the installation dolly, couplings and washer installation tool were modified.

Supply difficulties during the trial led to the DSI Omega 24 bolt (ERB024 bolt manufactured by Rautaruukki in Sweden) being introduced in October 2006 to replace the Swellex Mn24. Other similar bolts on the market include the Excalibur 240 (Sandvik), the Expanbol Super (Emcor) and the Wibolt Exp 20 (Minova). The Excalibur was more expensive than both Atlas Copco and DSI. The Expanbol bolt was eliminated following pull test results on surface in September 2006. The Wibolt was not tested. 
Table 1 Trial history

\begin{tabular}{|c|c|}
\hline Date & Details \\
\hline June 2005 & Initial contact made with Atlas Copco. \\
\hline \multirow[t]{3}{*}{ August 2005} & $\begin{array}{l}\text { First trials of Mn16 and Mn24 bolts. Bolts installed manually using } \\
\text { the HC1 (hydraulic pump) attached to the percussion line of the } \\
\text { Monomatic Jumbo. }\end{array}$ \\
\hline & $\begin{array}{l}1 \mathrm{x} \text { Mn16 failed at } 13 \mathrm{t} \text { during pull tests and Mn16 bolts were rejected } \\
\text { as potential bolts. }\end{array}$ \\
\hline & $\begin{array}{l}\text { Order placed for } 100 \text { x } 2.4 \mathrm{~m} \text { Mn } 24 \text { bolts and } 100 \times 3.0 \mathrm{~m} \text { bolts with } \\
\text { standard } 89 \mathrm{kN} \text { rated Swellex plates. Bolts were installed manually } \\
\text { using wand and HC1 pump connected to locking pin outlets of IT. }\end{array}$ \\
\hline November 2005 & $\begin{array}{l}\text { Progressed to Jumbo trial with hired } \mathrm{H} 104 \text { from Atlas Copco, equipped } \\
\text { to install Swellex bolts. Installed } 2300 \text { bolts (container imported from } \\
\text { Sweden) as part of rehab cycle, i.e. following completion of ore drive } \\
\text { development. Rail centraliser bushing bored out for Swellex chuck. }\end{array}$ \\
\hline February 2006 & $\begin{array}{l}\text { In-cycle trial of Swellex with H104. Difficulties with equipment - drill } \\
\text { steel too long for the rail, the washer installation tool (WIT) did not } \\
\text { work as required, and the rig did not have feed pressure to push the } \\
\text { bolt and mesh to the backs. }\end{array}$ \\
\hline May 2006 & Swellex plates replaced with DSI Dragonfly combination plates. \\
\hline \multirow[t]{4}{*}{ June 2006} & $\begin{array}{l}\text { Swellex gear (ex-H104, bought from Atlas Copco) fitted to Monomatic } \\
\text { with in-cycle Swellex bolting commencing in ore drives. }\end{array}$ \\
\hline & $\begin{array}{l}\text { Installed a high pressure electric pump supplied by Sandvik (HD- } \\
\text { E300/21) (cost \$15600). }\end{array}$ \\
\hline & $\begin{array}{l}\text { Modified Swellex dolly by replacing brass spacer between seals with a } \\
\text { stainless steel spacer (due to excessive wear), removed two rubber } \\
\text { bushings and extended dolly (for rail extension and dual centraliser). }\end{array}$ \\
\hline & Installed 5900 Swellex bolts following initial trial of 2500. \\
\hline September 2006 & Laboratory load-deformation testing of Mn24 and Expanbol24 bolts. \\
\hline October 2006 & $\begin{array}{l}\text { Sourced equivalent bolt (Omega 24) from DSI (Ruukki) and spare high } \\
\text { pressure pump from OEM Group for around \$3000. Laboratory load- } \\
\text { deformation testing of Omega } 24 \text { bolts (Ruukki ERB240 bolts). }\end{array}$ \\
\hline May 2007 & $\begin{array}{l}\text { Installed OEM pump and Swellex/Omega gear installed on Powerclass } \\
\text { twin-boom jumbo with modified coupling between shank adapter and } \\
\text { chuck for extra strength. }\end{array}$ \\
\hline August 2007 & $\begin{array}{l}\text { Replaced electronically operated directional control valves ( } \$ 2500 \\
\text { each - used to grip and inflate bolts) with high pressure taps costing } \\
\$ 30 \text { each. }\end{array}$ \\
\hline
\end{tabular}

\section{Performance}

The capacity and performance of the bolts in relation to rock mass deformation, seismicity and the resistance to mobile equipment damage were the most critical requirements. Assessing damage from mobile equipment in the narrow ore drives relied on visual observations as the drives closed over time. Damage was no more than that suffered by split sets and threadbars.

In August 2005 pull testing was undertaken underground on the initial trial batch of hand-installed Mn16 and Mn24 bolts (Figure 2). The expandable section of the bolts was limited to $380 \mathrm{~mm}$ to $400 \mathrm{~mm}$ by covering 
the remainder of the bolt with steel tube. The pull testing equipment only had a deformation range of $25 \mathrm{~mm}$ but the testing was sufficient to eliminate Mn16 bolts from the test programme and to approve further testing of Mn24 bolts. One of the Mn16 bolts suffered from steel tube failure at $130 \mathrm{kN}$, less than the capacity of a threadbar. The Mn 24 bolts typically slipped at $175 \mathrm{kN}$, with no steel failure.

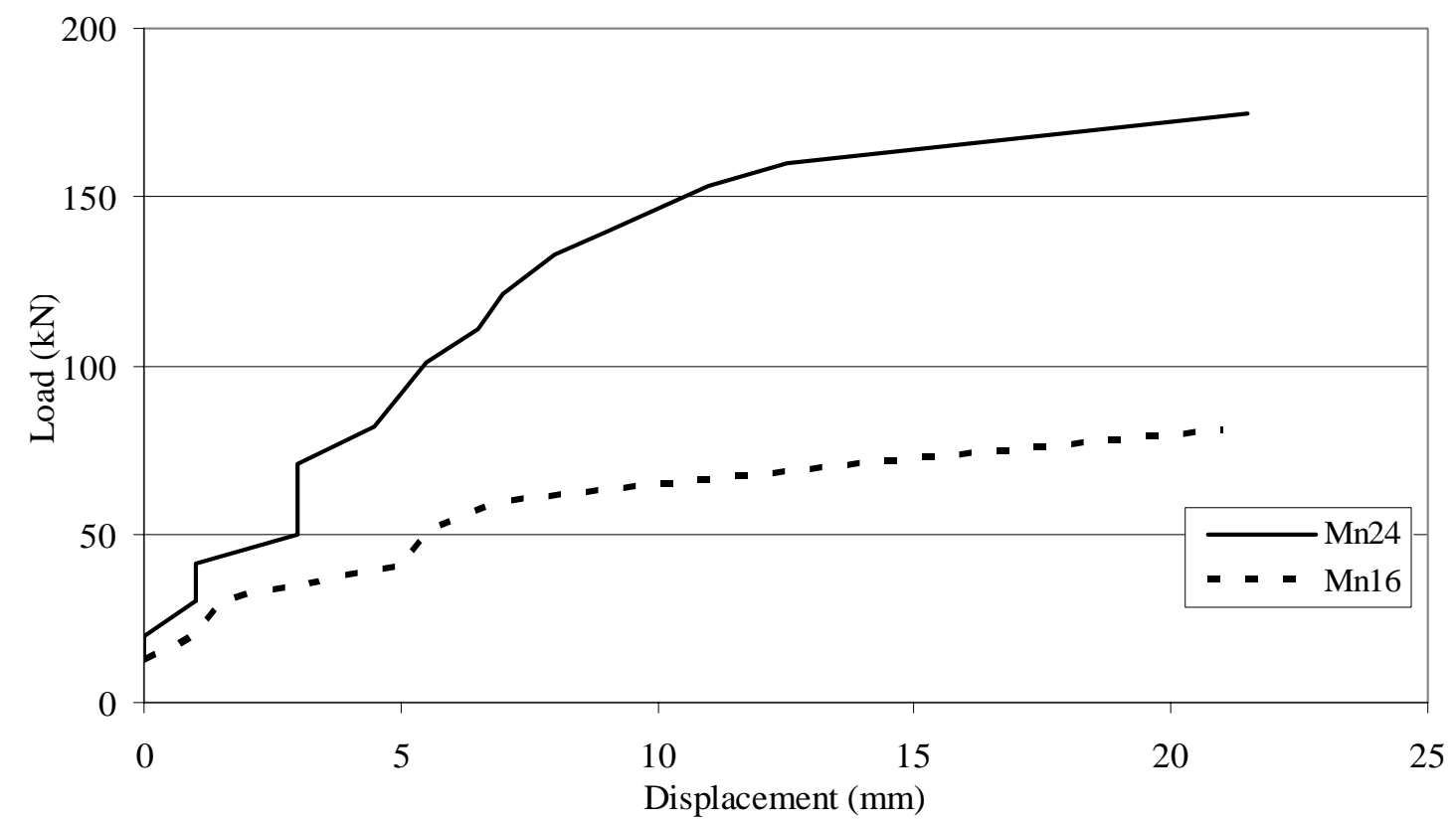

Figure 2 Underground load deformation results

In September and October 2006, a limited number of Mn24, Expanbol and DSI Omega 24 Bolts were pulltested in laboratories. The failure loads of the tubes and bushings were determined and also the full load deformation curve. The results (Table 2) showed consistent tube tensile strengths of over $23 \mathrm{t}$. Bushing weld tensile strengths of over $21.1 \mathrm{t}$ were obtained for the Omega and Mn24 bolts but the Expanbol failed at $16 \mathrm{t}$. Tube elongation of 20\% was achieved for the Omega bolt and 25\% for the Mn24, both less than the 30\% 'typical' capacity quoted in the manufacturer's technical literature, but still suitable to the underground requirements. The 6.5\% elongation for the Expanbol was insufficient for underground conditions.

Table 2 Laboratory test results

\begin{tabular}{lccc}
\hline Test & Mn24 & Omega 24 & Expanbol \\
\hline Tube strength & $23.4 \mathrm{t}$ & $23.6 \mathrm{t}$ & $25.6 \mathrm{t}$ \\
Tube elongation & $25 \%$ & $20 \%$ & $6.5 \%$ \\
Bushing weld strength & $>23.5 \mathrm{t}$ & $21 \mathrm{t}$ & $16 \mathrm{t}$ \\
\hline
\end{tabular}

The load deformation curve (Figure 3) shows a very favourable performance over most of the deformation range for the Omega and Mn24 bolts. The underground results for the Mn24 are also included in Figure 3 for comparison.

The performance of the bolts under seismic loading has been determined from observations underground following rockbursts and events close to excavations.

The Mn24 and Omega 24 bolts have performed at least as well as threadbars under seismic conditions, with no observed failures. The site of a recent event $\left(\mathrm{M}_{\mathrm{L}}=0.9\right.$, local Richter equivalent, (ISS, 2006)) on the edge of the access drive to 43F2 is shown in Figure 4, with deformation of rockbolt plates visible and bulging of mesh between the bolts. It should be noted that every attempt is made during design and excavation to eliminate the risk of rockbursts. 
The bolts currently installed in ore drives have to last a maximum of 18 months and corrosion is not expected to be an issue. Bolts in the decline will have to last for the remaining life of the mine but the environment is benign relative to the ore drives, with no time-dependant deformation, sulphides or groundwater.

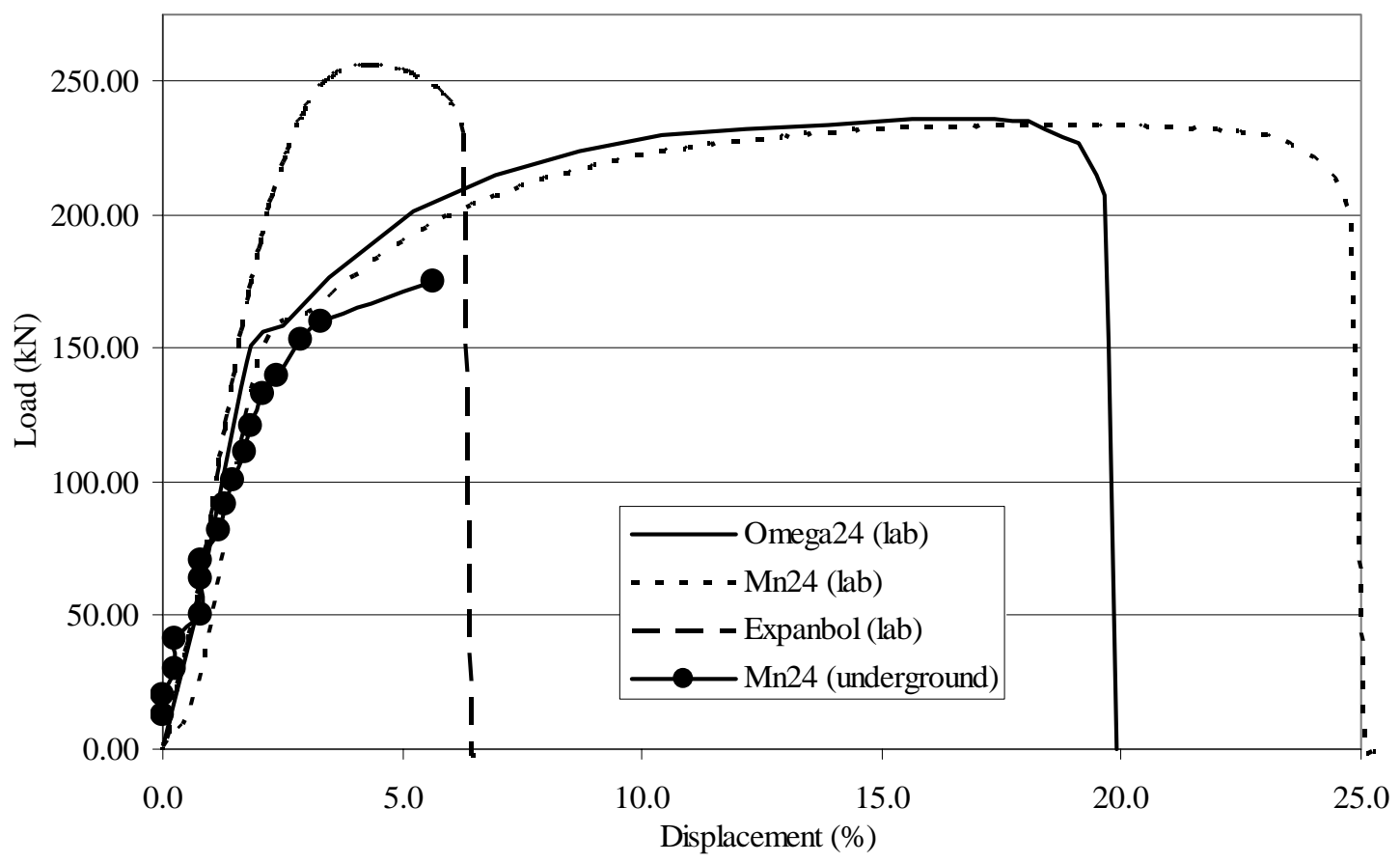

\section{Figure 3 Laboratory load deformation results}

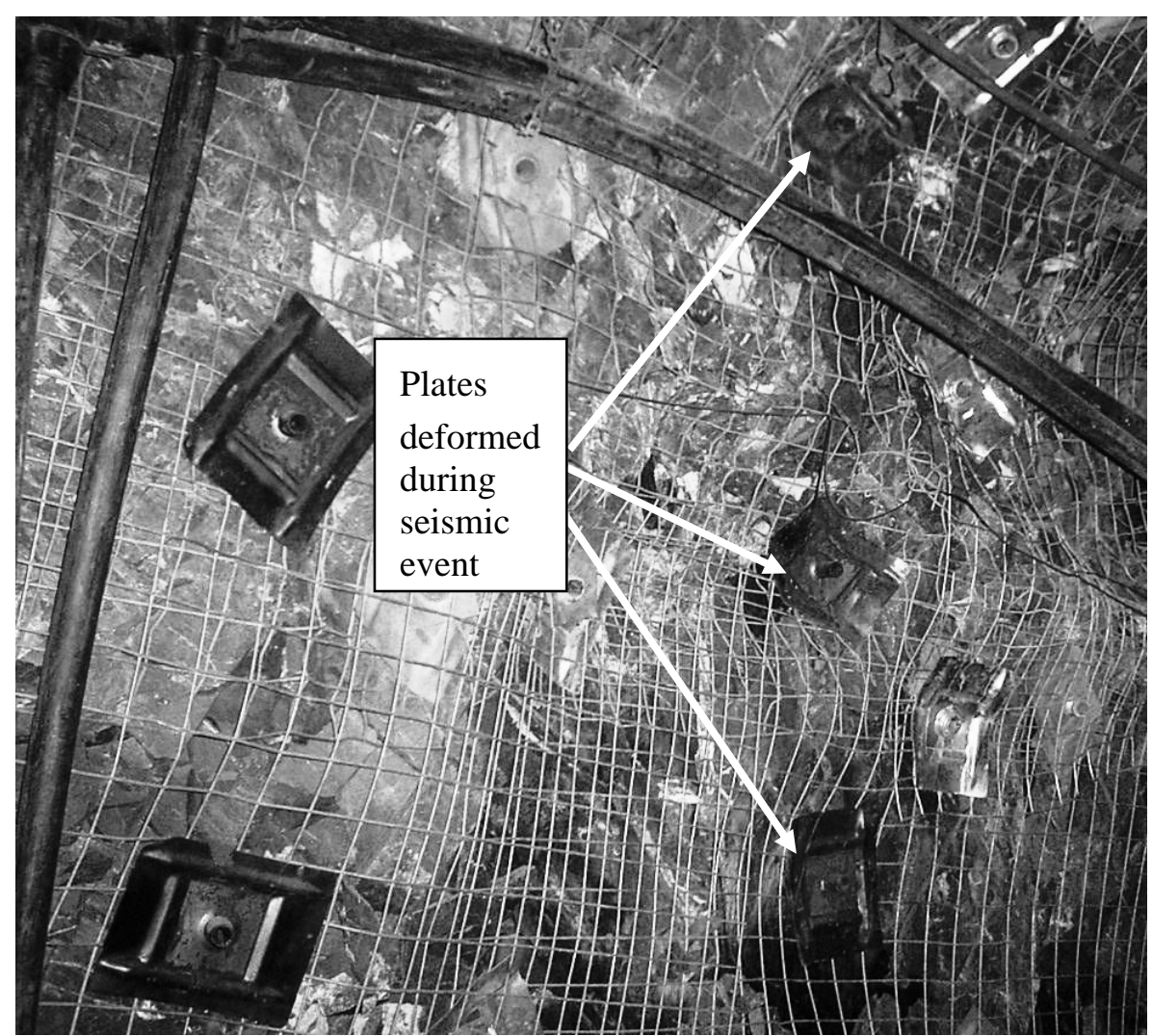

Figure 4 Controlled seismic event 


\section{Support pattern}

$2.4 \mathrm{~m}$ Omega 24 bolts are being used in a single-pass support system in 3.5 x $3.5 \mathrm{~m}$ ore drives. The bolts are used in combination with 2.4 m SS47 split sets, F51 galvanised mesh and SS39 stubby bolts. DSI Dragonfly combination plates are used with the Omega bolts as they are more robust and load-spreading than the original Swellex plates ( $150 \times 150$ × $6 \mathrm{~mm}$ dome plate with a 400 × $280 \mathrm{~mm}$ Dragonfly plate compared to 150 x 150 x 4 mm plate).

The first row of bolts next to the face is made up of split sets, mainly to facilitate pinning of mesh with stubby split sets in the mesh-overlap zone. There was also a perceived elevated risk of blast damage to the Omega bolts bushings compared to split sets and the necessity to double-up on Omega bolts at the meshoverlap if they were installed in the first row. Swellex mesh-pinning plates were eliminated early in the trial due to their low strength.

The middle row of bolts is made up solely of 7 Omega bolts, installed in the middle of the mesh. The mesh overlap row is made up of Omega bolts and stubby split sets. A photograph showing recent support in an ore drive is included in Figure 5 and the support design per row is shown in Figure 6.

Split sets without plates are also routinely used as spiling bars in the ore drives and two Omega bolts are installed below the mesh per cut on each side of the drive as wall support.

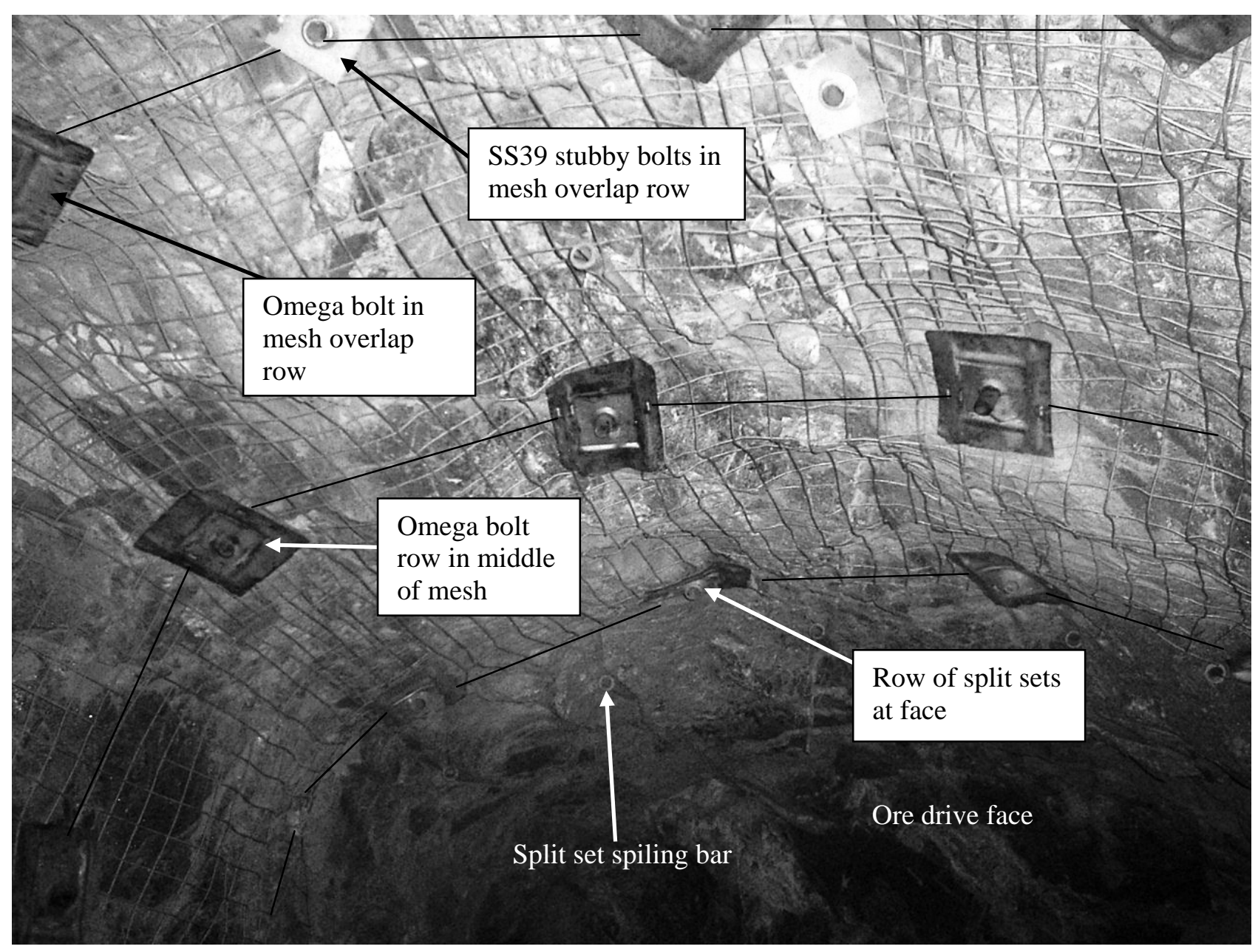

Figure 5 Ore drive support with Omega bolts 


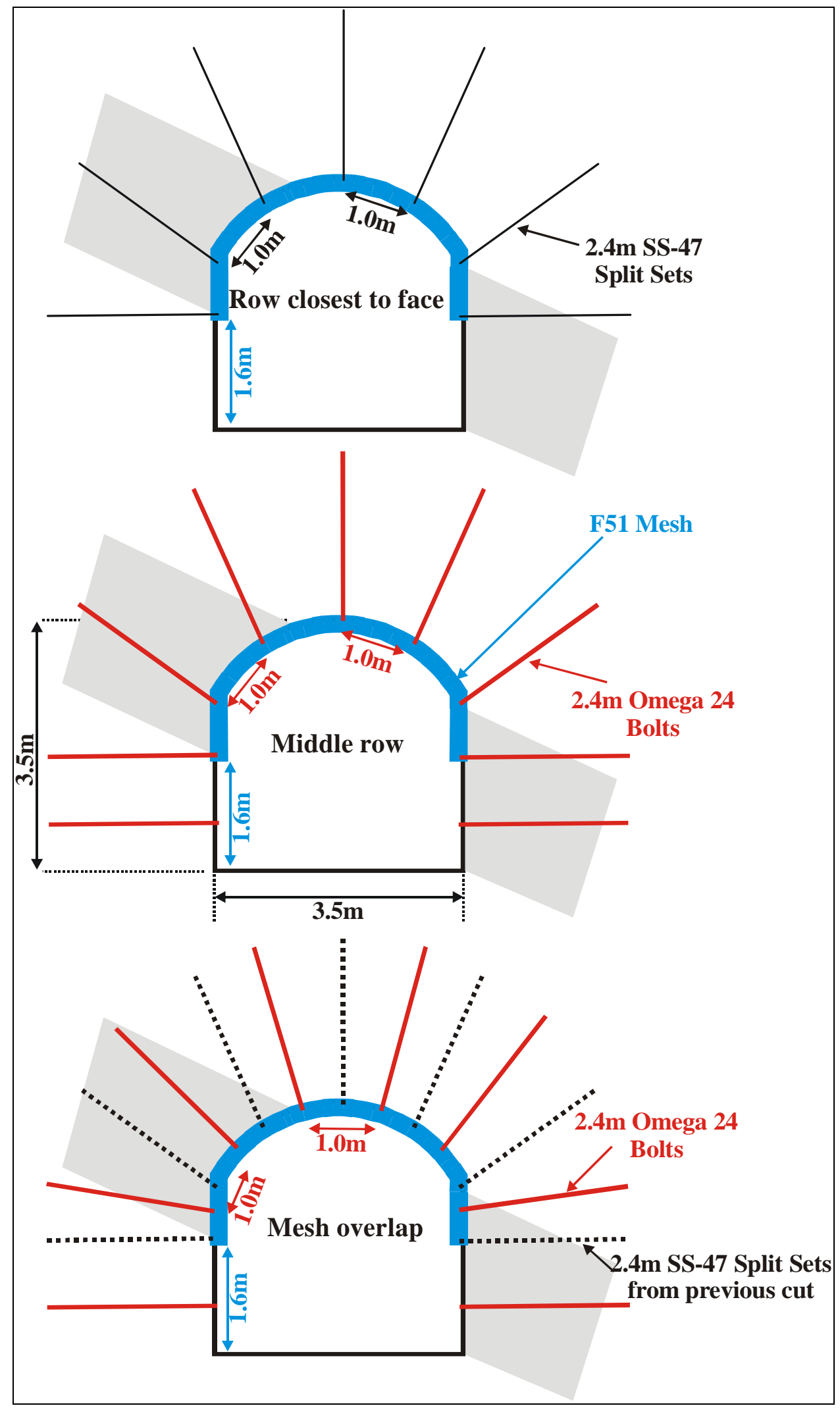

Figure 6 Ore drive support standard 


\section{Costs}

Reducing the cost of installed support was not a primary objective of the trial. The reduction in the number of holes required per $3 \mathrm{~m}$ cut from 32 to 24, did however, result in the cost of bolting per metre reducing from $\$ 941$ to $\$ 845$ with the single pass inflatable rockbolt system (Table 3). These costs include bolts and drilling costs. The major financial benefits have been the ability to maintain the same development rate and to eliminate the requirement for an airleg miner installing threadbars.

Table 3 Rockbolt cost comparison

\begin{tabular}{lclc}
\hline Previous standard & & \multicolumn{2}{l}{ Inflatable rockbolt standard } \\
\hline 3 m cut & & 3 m cut & \\
2 Rings x 7 SS47 & $\$ 1148$ & 1 Ring x 7 Omega24 & $\$ 733$ \\
1 Ring x 7 SS39 & $\$ 182$ & 1 Ring x 6 Omega24 & $\$ 628$ \\
2 Rings x 8 threadbar & $\$ 1328$ & 1 Ring x 7 SS47 & $\$ 574$ \\
2 x SS47 (walls) & $\$ 164$ & 7 x SS39 & $\$ 182$ \\
& & 4 x Omega24 (walls) & $\$ 419$ \\
Rockbolt cost per cut & $\$ 2822$ & Rockbolt cost per cut & $\$ 2536$ \\
& 16 & Jumbo holes & 24 \\
Jumbo holes & 16 & Airleg holes & 0 \\
Total holes & 32 & Total holes & 24 \\
Total cost per metre & $\$ 941$ & Total cost per metre & $\$ 845$ \\
\hline
\end{tabular}

\section{Conclusion}

The trial proved successful and the bolts coped with the severe deformations and occasional seismicity. In places the bolts even appear to have had a beneficial effect on ground conditions relative to split sets and threadbars. Current consumption is around 84 bolts per day in 4 headings.

Although cost had no bearing on the trial, the installed cost of ground support per metre (including: supply, drill and install) using the single-pass inflatable rockbolt system was cheaper than the two-pass split set and threadbar system. The reduction in cost from $\$ 941$ per metre to $\$ 845$ per metre was a result of fewer holes being required per cut (24 instead of 32). A major benefit was also the removal of an airleg miner from the ore drives.

Changing rockbolts in a deep high-stress environment such as Otter-Juan is not just a simple matter of installing a new type of bolt and carrying on mining. The extended length of the trial was necessary to ensure the bolt would perform as required, would be simple to install, the equipment would be reliable and bolt supply guaranteed by the supplier.

\section{Acknowledgements}

The authors wish to acknowledge the assistance provided by GMM managers and employees in the introduction of a replacement rockbolt at Otter-Juan. The managers (Peter Teasdale and Paul Fyfe) backed the trial for the whole period. Many miners are resistant to change but the jumbo operators at Otter-Juan (Lance Titchener and John Dowrick) saw very early on the potential benefits of a single-pass support system and persevered with the trials until all the issues were sorted out. The maintenance crew of Simon Taranto and Darren Appleton also made many modifications to equipment in order to make installation easier and to minimise breakdowns. 


\section{References}

AMC (1998) Otter-Juan Nickel Complex, 31 Level Virgin Stress Measurement. Australian Mining Consultants report 198063, December.

Banasik, C. (2003) The Pitfalls of Exploring A Shallow Dipping Orebody At Depth - A Case Study. Otter-Juan Mine, Kambalda, WA. $12^{\text {th }}$ International Symposium on Mine Planning and Equipment Selection, Kalgoorlie, Western Australia, April 23-25, 2003.

Gresham, J.J. and Loftus-Hills, G.D. (1981) The Geology of the Kambalda Nickel Field, Western Australia. Economic Geology, Vol. 76, pp. 1373-1416.

ISS (2006) Glossary of terms used in Routine Mine Seismology, ISS International document number REP-GLOS001r0, September.

Turner, M. and Green T. (2005) Threadbar Bolts in a Seismically Active, High Stress, High Yield Environment - OtterJuan Mine, Kambalda. Proceedings $6^{\text {th }}$ International Symposium on Rockburst and Seismicity in Mines. Potvin Y. and Hudyma M. (eds), Australian Centre for Geomechanics, Perth, March, pp. 67-73.

Turner, M., Teasdale, P. and Green, T. (2004) A Step back in time to Hand-Held Mining for Profitability. $2^{\text {nd }}$ International Symposium on Mining Techniques Of Narrow-Vein Deposits, CIM, Val d’Or, October. 